\title{
СПЕЦИФІКА ЕМОЦІЙНИХ БАР'ЄРІВ СПІЛКУВАННЯ У НЕПОВНОЛІТНІХ ЗАСУДЖЕННИХ
}

Статтю присвячено проблемі визначення особливостей емоційних бар'єрів у спілкуванні неповнолітніх засуджених. Коротко проаналізовано вплив бар'єрів спілкування на загальний процес комунікації та внутрішній психоемоційний стан підлітка. Зазначені наслідки емоційних бар'єрів спілкування для процесу соціалізації у підлітковому віці. Описані результати дослідження особливостей емоційних бар'єрів спілкування у неповнолітніх засуджених, здійснено порівняння їх з особливостями емоційних бар'єрів спілкування підлітків з нормативною поведінкою. З'ясовано, що неповнолітні засуджені відрізняються більшою виразністю певних психологічних проявів, які можуть стати емоційними бар'єрами спілкування: неадекватним проявом емоцій (схильність до неадекватного вираження емоцій, невідповідність емоційних реакцій тій реальній ситуації, в якій відбувається спілкування тощо); нерозвиненістю емоцій (емоційна скутість, стриманість, знижена здатність довільно регулювати прояви різноманітних емоційних станів тощо); небажанням зближуватися з людьми на емоційній основі (орієнтація на уникнення емоційних контактів, схильність не виявляти симпатію, пригнічувати виявлення своїх емоцій). Акцентовано увагу на відсутності відмінностей між неповнолітніми засудженими та підлітками з умовно нормативною поведінкою за шкалами «Невміння керувати емоціями» та «Домінування негативних емоцій», що виражається у недостатній спроможності контролювати емоційні реакиії, стримувати або дозувати прояви негативних емоцій, внутрішній напруженості, негативно забарвленому ставленні до оточуючих та до певних соціальних ситуацій; домінуванні негативних емоційних переживань, вираженій тенденції до прояву негативних емоцій, незадоволеності та занепокоєнні людьми чи обставинами, зниженому настрої, песимізмі. Відсутність розбіжностей у даних проявах пояснена особливостями підліткового віку. 3 огляду на те, що зазначені психологічні прояви емоційних бар'єрів спілкування сучасними науковцями співвідносяться з рівнем розвитку здібностей емоційного інтелекту у перспективі подальших досліджень запропоновано здійснити перевірку існування даного взаємозв'язку на вибірці неповнолітніх засуджених.

Ключові слова: спілкування, емоційні бар'єри, неповнолітні засуджені, підлітки з нормативною поведінкою, емоційний контроль, емоційна скутість, емоційний інтелект.

Постановка проблеми. Проблема спілкування завжди привертала увагу науковців, особливо у такому важливому для життя людини періоді - підлітковому віці. Багатьма дослідниками спілкування з однолітками вважається провідною діяльністю дітей цього віку $[1,10,18]$ “Спілкування з однолітками знаходиться у центрі життя підлітка і багато в чому визначає всі інші сторони його поведінки і діяльності", зазначає О.Ф. Іванова [7, с.22]. Головна потреба періоду - знайти своє місце в суспільстві, бути значущим реалізується у спільноті однолітків.

Особливістю підліткового спілкування є виникнення різного роду труднощів. Проблема труднощів або як їх ще називають "бар'єрів" спілкування широко вивчається вітчизняними i зарубіжними психологами. Вагомі внески у розробку цієї проблеми здійснили О.О. Бодальов, Л.П. Буєва, А.С. Золотнякова, М.С. Каган, Б.Д. Паригін, Е. Берн, 3. Фрейд.

Психологічні бар'єри спілкування характеризуються особливим психічним станом, який може виявлятися у наступному: пасивності людини, яка в подальшому перешкоджає здійсненню діяльності; актуалізації специфрічних психологічних настанов, переважно - деструктивних, які асоціюються із наявними завданнями; виникненням емоцій негативної модальності [3].

Як зазначає О.Ф. Джиоєва бар'єри спілкування сприяють втраті та викривленню сенсу інформації в процесі взаємодії, знижують ефективність комунікації, сприяють породженню негативних переживань, часто виступають причиною конфрліктних ситуацій [6, с.116].

Також, бар'єри спілкування в підлітковому віці являють собою певний конфрлікт між психологічними особливостями і зовнішньою ситуацією, взаємовплив яких породжує негативні переживання [6, с.117]. Психологічний бар'єр, як відзначає Є.Р. Чернобродов, стає причиною відчуженості і замкнутості, схильності до конфрліктів і негативізму; протиправні дії найчастіше $є$ засобами самоствердження, фрормування авторитету в підлітковому середовищі [17, с. 92]. 
Серед видів психологічних бар'єрів у спілкуванні вчені виокремлюють емоційні бар'єри, змістом яких виступають емоції великої інтенсивності, найчастіше негативного змісту, котрі виступають перешкодою самореалізації особистості в процесі спілкування [9, с. 352].

Як зазначає Л.О. Регуш, у підлітковому віці наявність виражених та стійких емоційних бар'єрів не лише ускладнює процес спілкування 3 однолітками та дорослими, що пригнічує процес соціалізації, а й дизгармонізує психічний розвиток підлітків, що може чинити негативний вплив на їх психологічне здоров'я. Існування таких емоційних бар'єрів формує неконструктивні, стереотипні, ригідні способи взаємодії підлітка із соціальним оточенням та з власним Я [14].

Для підлітків $є$ дуже важливим бути прийнятими оточуючими, певною групою, переважно однолітків. Проте через наявні емоційні бар'єри спілкування інколи фрормується побоювання та занепокоєння, що вони можуть бути відторгненими, не прийнятими групою.

Проблеми спілкування неповнолітніх засуджених та їх емоційні бар'єри спілкування науковцями практично не досліджувалися. Проте деякі автори опосередковано торкалися питання рівня компетентності у ссрері міжособистісного спілкування неповнолітніх засуджених. Цікавими для нашого дослідження $€$ висновки зроблені О. В. Форотинською про те, що неповнолітні злочинці відчувають себе менш компетентними у міжособистісному спілкуванні; менше відчувають контроль за процесом міжособистісного спілкування; менше покладають на себе причинність результату спілкування [16, с.287]. Московченко В.В. досліджувала специфіку спілкування делінквенних підлітків у контексті їх життєздатності, особливу увагу приділяючи таким характеристикам як соціальна тривожність та соціофобія [11]. Відсутність сучасних наукових досліджень з проблем емоційних ускладнень спілкування у неповнолітніх засуджених обумовили вибір теми нашої роботи.

Метою дослідження стало виявлення особливостей емоційних бар'єрів спілкування у неповнолітніх засуджених та порівняння їх з особливостями емоційних бар'єрів спілкування підлітків 3 нормативною поведінкою.
Виклад основного матеріалу. В якості психодіагностичного інструментарію для досягнення поставленої мети було застосовано методику «Діагностика емоційних бар'єрів в міжособистісному спілкуванні» В.В. Бойка. Методика складається з 25 питань, що розподілені за шкалами «Невміння керувати емоціями», «Неадекватний прояв емоцій», «Нерозвиненість емоцій», «Домінування негативних емоцій», «Небажання зближуватися з людьми на емоційній основі»[14, с. 166-167].

Статистична обробка результатів здійснювалась з використанням t-критерію Стьюдента для незалежних вибірок.

Вибірку склали 400 підлітків, які були розподілені на дві групи.

Допершої групи увійшлинеповнолітні засуджені чоловічої статі у кількості 184 особи - підлітки, які відбувають покарання у Державній установі «Курязька виховна колонія ім. А.С. Макаренка»«. Другу групу склали 216 підлітків з умовно нормативною поведінкою - учні загальноосвітніх шкіл м. Харків.

Результати дослідження представлені у наступній таблиці

У першій групі визначено вірогідно більший показник порівняно 3 другою за шкалами «Неадекватний прояв емоцій» ( $p \leq 0,001)$, «Нерозвиненість емоцій» $(p \leq 0,01)$ та «Небажання зближуватися 3 людьми на емоційній основі» $(p \leq 0,05)$.

Таким чином, неповнолітні засуджені відрізняються більшою виразністю таких психологічних проявів як:

- схильність до неадекватного вираження емоцій, неприродність та невідповідність емоційних реакцій тій реальній ситуації, в якій відбувається спілкування;

- емоційна скутість, стриманість, знижена здатність щодо вираження партнеру за спілкуванням емоційної підтримки через співчуття або співпереживання, знижена спроможність довільно регулювати прояв різноманітних емоційних станів;

- відсутність бажання формувати близькі стосунки на емоційній основі, орієнтація на уникнення емоційних контактів, схильність не виявляти симпатію до партнерів за спілкуванням, пригнічувати виявлення своїх емоцій; відчуття напруженості

Таблиця 1

Показники емоційних перешкод у міжособистісному спілкуванні у неповнолітніх засуджених та підлітків з нормативною поведінкою ( $\mathrm{M} \pm \mathrm{m}$ )

\begin{tabular}{|c|c|c|c|c|}
\hline Шкали & 1 група & 2 група & $\mathbf{t}$ & $\mathbf{p}$ \\
\hline Невміння керувати емоціями & $2,94 \pm 0,22$ & $2,68 \pm 0,17$ & 0,94 & - \\
\hline Неадекватний прояв емоцій & $3,41 \pm 0,33$ & $1,21 \pm 0,19$ & 6,04 & 0,001 \\
\hline Нерозвиненість емоцій & $3,74 \pm 0,34$ & $2,41 \pm 0,30$ & 2,93 & 0,01 \\
\hline Домінування негативних емоцій & $2,28 \pm 0,35$ & $1,54 \pm 0,28$ & 1,65 & - \\
\hline Небажання зближуватися з людьми на емоційній основі & $2,43 \pm 0,45$ & $1,41 \pm 0,22$ & 2,04 & 0,05 \\
\hline
\end{tabular}


або дискомфорту в межах спілкування, що характеризується неформальністю.

Не було встановлено відмінностей між групами за шкалами «Невміння керувати емоціями» та «Домінування негативних емоцій».

Отже, представники обох груп рівною мірою характеризуються наступним:

- недостатньою спроможністю контролювати емоційні реакції, стримувати або дозувати прояви негативних емоцій, внутрішньою напруженістю, негативно забарвленим ставленням до оточуючих та певних соціальних ситуацій;

- домінуванням негативних емоційних переживань, вираженою тенденцією до прояву негативних емоцій, незадоволеності та занепокоєння людьми чи обставинами, зниженого настрою, песимізму.

Відсутність відмінностей знаходить своє пояснення в особливостях підліткового віку. Психічний стан підлітка характеризується емоційною напруженістю. Це пов'язано з об'єктивними характеристиками самого пубертатного періоду, оскільки гормональні зміни, що відбуваються в його організмі, виступають певним каталізаторами майже всіх емоційних станів і проявів. Стає слабкішим функціонування коркових відділів головного мозку, страждає вся система регуляції поведінки. Крім того, за І. С. Коном, на середину пубертатного періоду припадає пік емоційної неврівноваженості [8]. Якщо дитина в цей час потрапляє в об'єктивно або суб'єктивно стресогенні обставини, може спостерігатися прояв дисгармонійних емоційних станів. За О.М. Семеновою, у підлітків переважають високий рівень тривожності, зниження оптимістичного сприйняття майбутнього, переживання душевного дискомфорту, агресивність, конфліктність поведінки, амбівалентність емоцій [2].

Низький рівень контролю емоційних реакцій сучасні науковці ще співвідносять із здібностями емоційного інтелекту (О.І. Власова, J. Mayer, P. Salovey) [4]. В наших попередніх дослідженнях ми також знайшли підтвердження існування взаємозв'язку між агресивними проявами, ставленням до оточуючих, відчуттям тривожності та емоційним інтелектом підлітків [12, 12]. Ми встановили наступне: чим вищий рівень розвитку емоційного інтелекту тим нижчі прояви агресії та ворожості та, ймовірно, краще виявлене позитивне ставлення до оточуючих людей; чим вищий рівень розвитку емоційного інтелекту тим нижча сенситивність до емоціогенних подразників, яка виражена в ситуативній та особистісній тривожності [13, с.116]; чим нижчий рівень розвитку емоційного інтелекту, тим частіше особа переживає негативні емоції взагалі та негативні емоції викликані стосунками з іншими людьми зокрема, та гірше контролює інтенсивність їх прояву, частіше переживає негативні емоції стосовно зовнішніх подій [12, с.146].
Таким чином, результати дослідження викладеного в даній статті засвідчили, що спілкування неповнолітніх засуджених демонструє наявність емоційних перешкод, які можуть проявлятися у схильності до неадекватного вираження емоцій, неприродності та невідповідності емоційних реакцій тій реальній ситуації, в якій відбувається спілкування; емоційній скутості, стриманості, обмеженій здатності до вираження співчуття або співпереживання, зниженій здатності довільної регуляції емоційних станів; відсутності бажання до зближення на основі емоцій, уникнення емоційних контактів, проявів симпатії до партнерів спілкування, пригнічення власних емоцій; відчутті напруженості або дискомфорту в межах спілкування. Проте, рівень домінування негативних емоцій у спілкуванні та навички керувати емоціями виявилися приблизно однаковими як у неповнолітніх засуджених, так і у підлітків з нормативною поведінкою. Оскільки зазначені характеристики психологічного прояву емоційних бар'єрів спілкування сучасними науковцями співвідносяться з рівнем розвитку здібностей емоційного інтелекту вважаємо перспективою подальших досліджень здійснення перевірки факту існування даного взаємозв'язку у спілкуванні неповнолітніх засуджених.

\section{Література:}

1. Божович Л. И. Изучение мотивации поведения детей и подростков / под ред. Л. И. Божович и Л. В. Благонадежиной. - М.: «Педагогика», 1972. 352 c.

2. Варій М.Й. Загальна психологія : [навч. посібник] / М.Й. Варій. - Львів : Край, 2005. 315 с.

3. Васянович Г. П. Педагогічна етика : навч. посібник/ Г. П. Васянович. - Львів : «Норма», 2005. 344 с.

4. Власова О.І. Психологія соціальних здібностей: структура, динаміка, чинники розвитку: Монографрія. - К.: Видавничо-поліграфічний центр «Київський університет», 2005. 308с.

5. Дроздова Н. В. Формирование конструктивной стратегии преодоления студентом психологическихбарьеров в учебной деятельности: автореф. ... дис. канд. психол. наук: 19.00.07. Самара, 2009. 21c.

6. Джиоева О. Ф. Психологические барьеры общения в подростковом возрасте. Азимут научных исследований: педагогика и психология. 2016. Т. 5. №. 4. С. 115-117.

7. Іванова О.Ф., Балинська М.В. Емоційні бар'єри та емпатія в процесі міжособистісного спілкування підлітків з різного соціального оточення. Вісник Харківського національного універсиmету ім. В.Н. Каразіна. Серія “Психологія". 2014. № 1110. С. 22-26.

8. Кириленко Т.С. Психологія: емоційна сорера особистості : [навч. посібник] / Т.С. Кириленко. К.: Либідь, 2007. 256 с. 
9. Куницына В.Н. Межличностное общение: учеб. для вузов / В.Н. Куницына, Н.В. Казаринова, В.М. Погольша. - Спб.: Питер, 2001. 544 с.

10.Максимова Н. Ю. Основи психології девіантної поведінки: підручник / Н. Ю. Максимова. - К.: Видавничо-поліграфрічний центр «Київський університет», 2008. 439с.

11. Московченко В.В. Особливості соціальної тривоги та соціофообії у делінквенних підлітків . Право і безпека. Харків, 2016. Т. 61, № 2. C. $129-134$

12.Приймаченко О.М. Дослідження зовнішніх ознак емоційного інтелекту підлітків 15-17 років . Сучасна педагогіка та психологія: від теорії до практики: Матеріали всеукраїнської науково-практичної конференції. Запоріжжя: Класичний приватний університет, 2016. 152с. С.143-146.

13.Приймаченко О.М. Особливості прояву внутрішніх ознак різних рівнів сфрормованості емоційного інтелекту підлітків // «UChoice: 4P» Ukrainina Choice: Public Policy, Politics, Psychology: матеріали II міждисциплінарної науково-практичної конференції - Одеса:
Національний університет «Одеська юридична академія», 2016. 180с. С. 113-116

14.Регуш Л. А. Самоотношение подростков и переживание проблем школьной жизни. Известия Рос. гос. пед. ун-та им. А. И. Герцена. 2009. № 100 . C. $57-65$.

15.Фетискин Н.П. Социально-психологическая диагностика развития личности и малых групп / Н.П. Фетискин, В.В. Козлов, Г.М. Мануйлов. - М: Изд-во Института Психотерапии, 2005. $490 \mathrm{c.}$

16. Форотинська О. В Особливості локусу контролю неповнолітніх злочинців як складової їх особистісної відповідальності. Вісник Національного університету оборони Украӥни 5 (30) /2012, C. 284-288

17.Чернобродов Е.Р. Влияние эмоциональных состояний на мотивацию делинквентного поведения несовершеннолетних. Психопедагогика в правоохранительных органах, 2006, № 2(26). C.89-92.

18.Шиханцов Г. Г. Юридическая психология : учебник для вузов./ Отв. ред.: Томсинов В.А. - М. : Зерцало, 1998. 352 с.

\section{Pryimachenko O. M. Study of emotional barriers of communication in juvenile convicts}

The article is devoted to the problem of determining peculiarities of emotional barriers in communication of juvenile convicts. The influence of communication barriers on general communicative process and internal psycho-emotional state of the adolescent is briefly analyzed. The consequences of emotional barriers to communication for the socialization process in adolescence are mentioned. The results of the study of revealing the peculiarities of emotional barriers of communication in juvenile convicts are described, their comparison with the peculiarities of emotional barriers of communication of adolescents with normative behavior is made. It was found that juvenile convicts are different with some psychological manifestations that can become emotional barriers in communication: inadequate expression of emotions (unnatural emotional reactions to the real situation in which communication takes place.); underdevelopment of emotions (emotional rigidity, restraint, reduced ability to arbitrarily regulation of various emotional states, etc.); unwillingness to get closer to people on an emotional basis (focus on avoiding emotional contacts, the tendency not to show sympathy, to suppress the expression of their emotions, etc.). The lack of differences between juvenile convicts and adolescents with conditionally normative behavior on the scales "Inability to control emotions" and "Dominance of negative emotions" is emphasized, it is expressed in the following: insufficient ability to control emotional reactions, restrain or dose the manifestations of negative emotions, internal tension, negative attitude to others and certain social situations; dominance of negative emotional experiences, a pronounced tendency to the manifestation of negative emotions, dissatisfaction and concern with people or circumstances, low mood, pessimism. The absence of differences in these manifestations is explained by the peculiarities of adolescence. Regarding the fact that these psychological manifestations of emotional barriers to communication are correlated with the level of development of emotional intelligence it is proposed to test the existence of this relationship in a sample of juvenile convicts in the future study.

Key words: communication, emotional barriers, juvenile convicts, adolescents with normative behavior, emotional control, emotional rigidity, emotional intelligence. 